\title{
CHINA'S RISING DEMAND FOR "GREEN CITIES": EVIDENCE FROM CROSS-CITY REAL ESTATE PRICE HEDONICS
}

\author{
Siqi Zheng \\ Jing Cao \\ Matthew E. Kahn \\ Working Paper 16992 \\ http://www.nber.org/papers/w16992 \\ NATIONAL BUREAU OF ECONOMIC RESEARCH \\ 1050 Massachusetts Avenue \\ Cambridge, MA 02138 \\ April 2011
}

We thank Cong Sun for excellent research assistance. We thank the National Natural Science Foundation of China (No. 70973065 and No. 70803026), the Richard Ziman Real Estate Center at UCLA, and the Peking University - Lincoln Institute Center for Urban Development and Land Policy for their generous funding and research supports. The views expressed herein are those of the authors and do not necessarily reflect the views of the National Bureau of Economic Research.

NBER working papers are circulated for discussion and comment purposes. They have not been peerreviewed or been subject to the review by the NBER Board of Directors that accompanies official NBER publications.

(C) 2011 by Siqi Zheng, Jing Cao, and Matthew E. Kahn. All rights reserved. Short sections of text, not to exceed two paragraphs, may be quoted without explicit permission provided that full credit, including $(\odot)$ notice, is given to the source. 
China's Rising Demand for "Green Cities": Evidence from Cross-City Real Estate Price Hedonics Siqi Zheng, Jing Cao, and Matthew E. Kahn

NBER Working Paper No. 16992

April 2011

JEL No. Q53,R31

\section{ABSTRACT}

With the decline of the traditional hukou system, migrants in China have a broad set of cities to choose from. Within an open system of cities, compensating differentials theory predicts that local real estate prices will reflect the marginal valuation of non-market local public goods. More polluted cities will feature lower real estate prices. But, local pollution may be caused by booming local industries. To address such endogeneity concerns, we estimate hedonic regressions using an instrumental variable strategy based on "imports" of pollution from nearby sources. By documenting the importance of spatial emissions patterns, our study highlights how real estate prices in one city are affected by Pigouvian externalities originating in another location. On average, a 10\% decrease in imported neighbor pollution is associated with a $1.8 \%$ increase in local home prices.

Siqi Zheng

Institute of Real Estate Studies

Department of Construction Management

Tsinghua University

Beijing 100084, P. R. China

zhengsiqi@tsinghua.edu.cn

Jing Cao

School of Economics and Management

Tsinghua University

Haidian District, Beijing, 100084, China

caojing@sem.tsinghua.edu.cn
Matthew E. Kahn

UCLA Institute of the Environment

Department of Economics

Department of Public Policy

Box 951496

La Kretz Hall, Suite 300

Los Angeles, CA 90095-1496

and NBER

mkahn@ioe.ucla.edu 


\section{Introduction}

Many cities in China have extremely high air pollution levels. Based on ambient particulate concentration criteria of $\mathrm{PM}_{10}$, twelve of the twenty most polluted cities in the world are located in China (World Bank 2007b). ${ }^{1}$ In 2003, 53\% of the 341 monitored cities - accounting for 58 percent of the country's urban population reported annual average $\mathrm{PM}_{10}$ levels above $100 \mu \mathrm{g} / \mathrm{m}^{3}$, and $21 \%$ of cities reported $\mathrm{PM}_{10}$ levels above $150 \mu \mathrm{g} / \mathrm{m}^{3}$. Only one percent of China's urban population lives in cities that meet the European Union's air quality standard of $40 \mu \mathrm{g} / \mathrm{m}^{3}$ (World Bank 2007a).

Air pollution has caused severe health damage in China (Wang and Mauzerall 2006). The World Bank (2007a, 2009) estimates that 13\% of all urban premature deaths may be due to ambient air pollution. The overall health damage due to air pollution is roughly 3.8\% of GDP in China. (World Bank 2007a, 2009). Exposure to outdoor air pollutants increases the incidence of lung cancer, cardiorespiratory diseases and possibly low birth weight (Pope et al., 2002; Dockery et al., 1993; Almond et al., 2009).

With the recent decline of the traditional Chinese hukou system, falling cross-city migration costs means that urbanites in China can migrate to areas that offer higher quality of life (Zheng, et. al. 2009). The urban population is enjoying increased income and the average urbanite is increasingly well educated. Such households will be increasingly willing to pay more to protect their health and thus willing to pay more

\footnotetext{
${ }^{1}$ Particulate matter less than $10 \mu \mathrm{g}$ in diameter, i.e. finer particles, are typically used in health damage assessments.
} 
to avoid urban air pollution.

Hedonic pricing methods can be used to measure marginal valuations of location specific attributes such as air pollution. Based on compensating differentials logic, numerous U.S based studies have estimates the implicit prices of non-market goods ranging from climate, to pollution, to proximity to public transit (see Rosen 2002). Cross-city hedonic studies (see Berger, Blomquist and Hoen 1988, Gyourko and Tracy 1991) have ranked which U.S studies have the highest quality of life. Recent research has used similar techniques for 30 major cities to document that air pollution is capitalized into Chinese real estate prices (Zheng, Liu and Kahn 2010).

These past hedonic studies have used ordinary least squares to estimate the hedonic gradient. Such an estimation strategy is based on the assumption that the hedonic price equation's error term is uncorrelated with the regression's explanatory variables. But, environmental economists have argued that both local business cycles and the intensity of enforcement of local regulation would both lead to cases in which a city's pollution level is correlated with the hedonic regression's error term (Zabel and Kiel 2000).

Recent work in environmental economics based on U.S data has offered a credible instrumental variables strategy. Bayer, Keohane and Timmins (2009) instrument for a city's air pollution levels using nearby "origin" pollution that blows over to the "destination" city. Such emissions raise the destination's local ambient air pollution levels but are unlikely to be correlated with the hedonic pricing equation's error term. Other studies also find cross-border emission transport may contribute substantially to 
both source and downwind regions, therefore one city or region's air quality depends upon its own emissions and is affected by emissions from surrounding cities and regions (Tong and Mauzerall 2008, Liu et. al 2008).

In this paper, we use the Bayer, Keohane and Timmins (2009)'s instrumental variables strategy and argue that their logic is even more important in the case of China. We consider two main types of imported air pollution in Chinese cities: dust and smoke emissions from neighbor cities' manufacturing activities, and sandstorm emissions imported from the sandstorm origin in Inner Mongolia. Our calculations indicate that in a typical city, about $15 \%$ of air pollution in terms of PM10 blows in from neighbors and the sandstorm origin.

This paper's main empirical contribution is to provide new hedonic estimates of the implicit price of air pollution in 2006, 2007 and 2008 across 85 major Chinese cities. We find that the implicit real estate capitalization for exposure to air pollution is growing over time across China's cities and the estimates are larger when we instrument as compared to our OLS estimates. Such revealed preference evidence is useful for policy makers considering the benefits of specific public policies for reducing ambient air pollution.

The popular media has written in depth about the pollution challenges that Hong Kong faces. Much of this pollution has been imported from nearby Chinese manufacturing cities such as Zhaoqing, Qingyuan and Heyuan. Such cross-boundary Pigouvian externalities can have significant real estate market implications for those who live in the "importing" area. The extent of the pollution damage will depend on 
how many people live in the destination area and what is their marginal willingness to pay to avoid pollution is higher. We use our estimates to provide a rough guide to the potential size of these effects.

\section{Empirical Framework}

In this paper, we will estimate a cross-city hedonic pricing equation and an air pollution production function. This latter equation will be used as the first stage of two stage least squares. We begin by discussing the air pollution production function.

The Air Pollution Production Function

We will estimate a simple city level air pollution production function as reported in equation (1):

$\ln \left(P M_{i t}\right)=a_{0}+a_{1} \cdot X_{i t}+\alpha_{2} \cdot \ln \left(N_{E I G H B O R}\right)+\alpha_{3} \cdot \ln \left(S_{t i N D S T O R M}\right)+\alpha_{4} \cdot$ NORTH $_{i}$ $+\alpha_{5} \cdot N O R T H_{-} B O R D E R+\varepsilon_{i t}$

Where $P M_{i t}$ is the PM10 concentration in city $i$ in year $t, X_{i t}$ is a vector of city attributes that affect the city's PM10 concentration. This equation embodies standard measures of the scale of economic activity, climate conditions and industrial composition (output's share of manufacturing industry). In particular, the $\mathrm{X}$ vector includes such attributes such as city population $(P O P)$, the output share of 
manufacturing industry $(M A N U)$, rainfall $(R A I N)$, January temperature (JAN) and July temperature (JULY). Such reduced form estimates have been reported in U.S studies such as Kahn (1999).

The more novel feature of equation (1) is the last four explanatory variables. These will be our instrumental variables in our hedonic pricing equation we report below. The vector of instruments includes; NEIGHBOR, SANDSTORM, NORTH and NORTH_BORDER. We construct the NEIGHBOR variable to measure how city i's time $\mathrm{t}$ emissions is affected by nearby emissions from the $\mathrm{j}$ sources. ${ }^{2}$ Specifically, NEIGHBOR is defined as:

$$
\text { NEIGHBOR }_{i t}=\sum_{j} \text { smoke emission }_{j t} \cdot e^{-d_{i j}}, \quad d_{i j}>120 \mathrm{~km}
$$

Where smoke emission $_{j t}$ is city $j$ 's smoke emission in year $t$ (in $10^{6}$ tons). ${ }^{3} d_{i j}$ is the

\footnotetext{
${ }^{2}$ Recent atmospheric chemistry studies have documented the extent of cross-boundary pollution exports. Tong and Mauzerall (2008) highlight the importance of interstate emission transfer on local air quality, they use the CMAQ model simulate and construct a source-receptor matrix for all continental states of U.S. They found out over $80 \%$ of the contiguous states, interstate transport of NOx emissions is more important than local emissions for summertime peak ozone concentrations. Liu et al. (2008) conduct a similar source-receptor matrix of sulfur emissions focusing on East Asian emissions on other continental regions, they find that present-day East Asian $\mathrm{SO}_{2}$ emissions account for at least $20 \%$ of total sulfate concentrations over the North Pacific at the surface, and East Asian SO2 emissions account for approximately $30-50 \%$ and $10-20 \%$ of background sulfate at the surface over the Western and Eastern US. Saikawa et al. (2009) also apply MOZART-2 model, and find out China's aerosol emissions contribute significantly over neighboring regions by applying global models of chemical transport (MOZART-2) model. They estimate that, in the Korean peninsula and Japan, an annual average concentration of $1.4 \mu \mathrm{g} / \mathrm{m}^{3}$ of $\mathrm{PM}_{2.5}$ results from China's aerosol emissions.

${ }^{3}$ To better measure the imported pollution from all neighbor cities, we use the smoke emission information of all 286 prefecture-level (or above) cities to construct this NEIGHBOR variable.
} 
distance between local city $i$ and city $j$ (in thousand kilometers). $e^{-d_{i j}}$ is the value of a continuous and exponential decreasing function, so the weight declines as the distance between origin $\mathrm{j}$ and destination $\mathrm{i}$ increases. ${ }^{4}$ To minimize the likelihood that instrument is correlated with local city i's economic activity, we exclude all the neighbor cities within $120 \mathrm{~km}$ from local city $i$ in the above IV equation (i.e., $d_{i j}>120$ $\mathrm{km})$. This variable's correlation with city j's GDP per capita is extremely low (-0.04). "Sandstorms" represents a unique inter-regional long-distance transported pollutant. "Sandstorm" is mainly composed of fine sediments originating in arid and semi-arid regions, and transported by strong winds to about 17 provinces in China. Similar impacts are also detected in Korea, Japan and even the west coast of the United States and the southern British Columbia, Canada (Chun 2000; McKendry et al., 2001). There have been growing concerns about the health damages caused by Asian sandstorms. Based on a case study in Beijing, Ai (2003) estimates the economic costs of sandstorm are greater than $2.9 \%$ of Beijing's GDP in 2000. In our model, SANDSTORM is the distance to the sandstorm origin (Inner Mongolia). We use a logarithmic specification so the sandstorm's impact on a city's air quality also diminishes when the city moves further from the sandstorm origin.

The cities north of the Huai River and Qinling Mountains receive subsidized heating in winter months, while the southern cities are not entitled to centralized heating. This sector creates high emissions levels because heating's main energy

\footnotetext{
${ }^{4}$ It is worth noting that the wind direction may influence such inter-city pollution diffusion processes, so it should be included in Equation (2) as an adjustment for the weight matrix. We have not obtained reliable wind direction data at this stage, so we make a simple assumption that each direction has the same weight.
} 
source is coal (Almond et. al., 2009).We include two dummies: NORTH for the cities to the north of the Huai-River-and-Qinling-Mountains heating line, and NORTH_BORDER for a subgroup of northern cities adjacent to the line (within $400 \mathrm{~km}$ from the line).

\section{The Hedonic Home Price Equation}

To estimate a cross-city hedonic pricing gradient implicitly assumes that migration costs are low. Before the 1980s, cross-city labor migration had been strictly regulated by the hukou system. In the wake of transition to a market economy in 1980s, the regulation on population mobility was relaxed. Population mobility has substantially increased since then. During our sampling period (2006-2008), anyone with or without hukou can freely purchase houses in any cities, so the low migration cost assumption is plausible.

We estimate a series of pooled cross-sectional home price regressions. The equation is presented in equation (3).

$$
\ln \left(H P_{i t}\right)=\beta_{0}+\beta_{1} \cdot \ln \left(P O P_{i t}\right)+\beta_{2} \cdot A_{i t}+\beta_{3} \cdot \log \left(P M_{i t}\right)+\mu_{i t}
$$

Where $H P_{i t}$ is home price in city $i$ in year $t . A_{i t}$ are a vector of amenities in city $i$ in year $t$, which may include number of hospital beds per capita (SICKBED), number of school teachers per pupil (TEA_STU), and PM10 concentration (PM), and the temperature 
discomfort index (TEMP_INDEX, see Zheng, et. al. (2010) for definition). This regression allows us to test for the size and statistical significance of amenity effectsand the city's population scale effect.

OLS estimates of equation (3) may yield inconsistent results of $\beta_{3}$ for at least two different reasons. First, air pollution is likely to be higher in those cities experiencing an industrial boom. Such cities will have more economic activity taking place (a scale effect) and for many of such cities the active industries will include high polluting industries (such as steel production). The environmental regulation "J-curve" hypothesis offers a second explanation for why it may be a mistake to treat air pollution as an exogenous attribute. In a cross-national model, Selden and Song (1995) argued that richer nations are more likely to enact more stringent environmental regulation. If regulation is effective at lowering air pollution, then air pollution will be low in those areas that have effective, wealthy government. It would not be surprising that home prices will be high in such areas.

We will report both OLS and IV (for PM and POP) hedonic estimates of the hedonic pricing equation. We are concerned about possible endogeneity of PM10 for two different reasons. If booming cities (due to dirty industry) have high home prices, then this will tend to bias the OLS estimates of PM10 towards zero and in fact we could find that high pollution cities have higher real estate prices (because PM10 proxies for industrial activity). Alternatively, if good governance cities have low PM10 then we may overstate the direct effect of PM10 because it proxies in part for good governance along a variety of dimensions (such as garbage pick-up and general "greenness"). 
We instrument for $\log (P M)$ using the pollution production function (Equation (1)). The key identifying assumption is that the exogenous variables such as NEIGHBOR, SANDSTORM, NORTH and NORTH_BORDER will act as our set of instruments for

PM10. For these to be valid instruments they must determine a city's PM10 level (due to the spillover effect) but that are uncorrelated with the error term in equation (2).

We are also concerned about the endogeneity of city population size $(P O P)$. As documented in the U.S literature, the population is likely to migrate to those cities that are highly productive and that have high amenities. The error term in equation (3) will capture the unobserved location specific attributes and the urban population may be correlated with this. To address this concern, we use the city's population twenty years ago (year 1985) and the above exogenous variables to instrument for current city population. The year 1985 is the earliest year for which we have access to accurate city population statistics. In addition, year 1985 was the very beginning of China's market economy so before that year there had been very little cross-city/rural-to-urban migration.

\section{The Wage Equation}

We will also estimate a wage regression to see if urban workers in polluted cities are compensated by earning higher wage. Our wage equation is similar to the hedonic pricing equation: 


$$
\ln \left(W A G E_{i t}\right)=\gamma_{0}+\gamma_{1} \cdot \ln \left(P O P_{i t}\right)+\gamma_{2} \cdot A_{i t}+\gamma_{3} \cdot \log \left(P M_{i t}\right)+\pi_{i t}
$$

Where $W A G E_{i t}$ is the city wage rate for city $i$ in year $t$.

We will estimate equations (1) to (4) in each calendar year from 2006 to 2008. This allows for a simple test of whether the pollution capitalization effect is growing over time. China's booming growth and rising educational attainment both suggest that this capitalization should be growing over time.

\section{Data and Empirical Results}

We restrict our empirical analysis to 85 mainland cities (we do not include Hong Kong due to a data inconsistency problem). We obtain our city-level data from two main sources. City population, average home price and most of the amenity variables come from the China Statistic Yearbooks, China Urban Statistic Yearbooks and the China Regional Statistic Yearbooks. PM10 concentration data comes from the Data Center of PRC's Ministry of Environmental Protection (http://datacenter.mep.gov.cn/), which is estimated from the official Air Pollution Index (API) based on the MEP API calculation formula. Since the PM10 data only cover the years 2006 to 2009, while the home price data covers the years 2005 to 2008 for 85 cities, we restrict our analysis to the 2006-2008 period. Variable definitions and summary statistics are listed in Table 1. 
*** Insert Table 1 about here ***

The home price represents the average sales price of newly-built commodity housing units. Commodity housing sales account for the majority of the housing transactions (more than 70\%) in Chinese cities. There is no reliable price data for second-handed housing unit sales so we rely on this commodity housing price measure. The average annualized home price growth rate was $17 \%$ for this time period. In 2008 , the most expensive city is Shenzhen $(12,823 \mathrm{RMB}$ per square meter), and the cheapest city is Kelamayi (1,431 RMB per square meter). ${ }^{6}$ This large cross-city price variation is due to productivity and amenity differentials.

Air quality in Chinese cities has been improving over time. The average PM10 concentration was $0.098,0.092$ and $0.088 \mathrm{mg} / \mathrm{m}^{3}$ for the years 2006, 2007 and 2008, respectively. Beijing experienced a great air quality improvement in these three years $\left(0.162,0.149,0.124 \mathrm{mg} / \mathrm{m}^{3}\right.$ for $2006,2007,2008$ respectively) due to factory shutdowns and short-term traffic control policies introduced before the 2008 Olympic Game. PM10 concentrations vary significantly across cities. In 2008, the dirtiest city (Wulumuqi) had a PM10 concentration level $\left(0.149 \mathrm{mg} / \mathrm{m}^{3}\right)$ four times higher than the cleanest city (Liuzhou, $\left.0.037 \mathrm{mg} / \mathrm{m}^{3}\right)^{7}$

\footnotetext{
${ }^{6}$ The exchange rate is roughly 7 RMB per U.S dollar.

${ }^{7}$ China's API data has been debated regarding its data quality. For instance, Wang et al. (2009) found his self-measured PM level in Beijing during Olympic period is correlated with official API, but 30\% higher. Andrews (2008) pointed out a likely systematic downward-bias around the "Blue Sky" standard (API less or equal to 100), and also highlighted a sampling downward bias for dropping monitoring stations in more pollution concentrated traffic areas in Beijing. These studies triggered some concerns on the measurement errors using Chinese official API data.
} 


\section{Empirical results}

Table 2 reports a series of air pollution production regressions. We run this regression (Equation (1)) by year. Column (1), (3) and (5) are simple regressions without our IV variables for 2006, 2007 and 2008, respectively. First, the city size/ambient pollution elasticity equals roughly .11. The manufacturing share only has an insignificant effect on PM10 concentration. Rainfall is good for mitigating air pollution. This simple equation can explain $25 \%$ to $35 \%$ of the cross-city PM10 variation. In Column (2), (4) and (6) our four cross-boundary variables are included in the regressions. We find that these IVs are jointly significant at $1 \%$ level in the PM production function and improve the explanation power $\left(R^{2}\right)$ by about 0.15 to 0.20 . Imported pollution from neighbor cities has a very significant effect (at the $1 \%$ level) on a local city's air pollution. In 2008, a $10 \%$ decrease of the NEIGHBOR variable reduces the PM10 concentration by $2.6 \%$. Holding other variables constant, the further away from Inner Mongolian (sandstorm origin), the better air quality a city has.

\footnotetext{
Later studies suggest that Wang's measurement gap between the self-measured data and official API data is mainly due to sampling and methodological differences (Tang et.al, 2009; Yao et.al, 2009, Simorich, 2009). A recent paper by Chen et al. (2011) use both API and AOD data to analyze the changes before and after Beijing Olympic, and their studies suggest two different data sources provide similar evidences. In our studies, we converted API index back to PM concentration data using the SEPA API formula. Even if there may be a downward bias around the standard ( API $=100$ ), its bias is only less than 5\% in the Beijing sample (Andrews, 2008, table 3), it only slightly change the API level at the margin. In addition, for the second reason addressed by Andrews, it is not likely all the cities are relocating monitoring stations for data manipulation purpose. So we believe our data based on the API converted PM concentrations would be reliable, the likely measurement errors would be small for our econometric analysis. Furthermore, if indeed there is a systematically bias for all the Chinese cities, such an error will not affect the regression analysis based on the relative changes across the cities at given time period.
} 
NORTH and NORTH_BORDER are insignificant. ${ }^{8}$

*** Insert Table 2 about here $* * *$

Figure One shows the spatial distribution of NEIGHBOR, thus we can see which cities are suffering the most from surrounding smoke emissions. Table 3 list the top ten cities based on imports of surrounding cities' emissions. We can see that the most suffered cities are located in the Central region because they are surrounded by other cities in all directions.

\author{
*** Insert Figure 1 about here *** \\ *** Insert Table 3 about here ***
}

Table 4 presents the hedonic real estate pricing regression results by year. In each year we run an OLS regression and two IV regressions. We discuss the OLS regressions first (Column (1), (4) and (7)). The first fact we learn from the home price regressions is that bigger cities have higher home prices. The cross-sectional elasticity is about 0.35 to 0.40 . We only find very weak and insignificant capitalization effects of a city's climate in home prices. The school teacher proxy also has a weak capitalization effect which

\footnotetext{
${ }^{8}$ While this result stands in contrast to Almond et. al.'s (2009) finding of a pollution jump just north of the border, it is important to note that we estimate a very different specification. They include a cubic in the geographical area's latitude while we include a vector of city specific attributes related to the scale and economic activity taking place within the city.
} 
may be due to that this is only a quantity rather than a quality measure. Number of hospital beds per capita has a significant positive effect on home prices. Cities in the East Region have a $40 \% \sim 50 \%$ higher price on average than cities in the Central and Western Regions. We acknowledge that we have a relatively "short" list of city attributes comparing to the U.S quality of life literature due to data availability problem. For example, we are unable to find city-level crime information.

Holding these other factors constant, we find consistent evidence that ambient particulate matter $(\mathrm{PM})$ is negatively correlated with home prices. Based on the OLS results, we estimate a pollution elasticity of between -.25 and -.37 .

*** Insert Table 4 about here $* * *$

As mentioned above, the OLS regressions may yield biased coefficient estimates of the PM effect due to possible endogeneity issues. To address this, we report instrumental variables estimates of equation (3) using equation (1) as our first stage. Our IV results are reported in Table Four's columns (2), (5), and (8). The IV estimates yield more negative PM10 elasticity estimates than the OLS results. This means that the cross-boundary externality has a significant impact on home prices. We also find clear evidence that Chinese urban residents' willingness-to-pay for clean air is increasing over time. In 2006, we estimate a PM10 elasticity of -.31 (see column (2)) and this grows sharply to -.76 in 2008 (see column (8)). We recognize that this is a huge growth in a marginal price coefficient in short period of time. The steepness of 
this trend merits further research. In 2008, we estimate that a $10 \%$ increase in a city's pollution is associated with a $7.1 \%$ reduction in local real estate prices.

To address the endogeneity of city population, in the second set of IV regressions we also instruct current city population using 1985 city population and other exogenous variables (Column (3), (6), (9)). We can see that the coefficients of $\log (\mathrm{POP})$ become smaller. The coefficients of $\log (\mathrm{PM})$ are similar but a little bit smaller than those in the first set of IV regressions. In 2006 this coefficient is marginally significant, while in 2007 and 2008 it is significant at 5\% and 1\% level, respectively.

Wage regression estimates of equation (4) are reported in Table 5. They show that the workers in polluted cities are not receiving higher wages. Population size is the dominant determinant of city wage rate.

\section{The Real Estate Market Consequences of Cross-Boundary Externalities}

Our results documenting both that pollution is "exported" across China and that pollution is capitalized in cross-city real estate prices highlights the importance of considering cross-boundary Pigouvian externalities and their consequences for a city's quality of life.

Based on our estimates of equation (1) and (3), we find that a $10 \%$ increase in the NEIGHBOR variable may trigger a $1.8 \%$ drop of local home prices. Similarly, a $10 \%$ increase of the city's distance to the sandstorm origin will contribute to a $2.3 \%$ increase of home price. 
If a major city's quality of life is threatened because it is downwind from major pollution sources than real estate prices will suffer. The extent of this Pigouvian externality hinges on several factors. Imagine a case in which there is significant cross boundary spillovers of pollution from location $i$ to location $j$ but that very few people live in location $j$ and these people are poor. The total damage caused by the pollution will be small as compared to an alternative case in which many wealthy people with a high willingness to pay to avoid pollution are exposed to downwind pollution.

Hong Kong represents a salient example. ${ }^{9}$ Hong Kong has been facing two air pollution issues. One is local street-level pollution mainly from auto-emissions from diesel vehicles. The other is the smog problem, caused by a combination of pollutants from motor vehicles, industry, and power plants both in Hong Kong and in the Pearl River Delta region. Much of this pollution has been imported from nearby Chinese manufacturing cities such as Zhaoqing, Qingyuan and Heyuan. Annual premature deaths attributed to the air pollution in 2008 are estimated at 1,200 in Hong Kong, and associated premature mortality losses amounts to 140 US\$ a year (Edgilis, 2009).

\section{Conclusion}

\footnotetext{
${ }^{9}$ Some scholars have examined the relationship between the air quality and housing price in Hong Kong. Almost all of the hedonic property literature all focuses on the local air quality. For example, Chau, Wong and Lam (2006) find air pollution has a significant negative impact on property prices, based on their semi-log regression, roughly an increase of $0.1 \mu \mathrm{g} / \mathrm{m} 3$ in the air pollution level (suspended particulates) lowers property prices by $1.28 \%$. Edgilis (2009) conduct a conservative estimate in the west and central area of Hong Kong, and find that a $10 \%$ drop in the level of $\mathrm{SO}_{2}$ emissions can raise property value by $3.2-3.9 \%$, and a $20 \%$ drop in $\mathrm{SO} 2$ emission can raise housing price by $6.5-7.9 \%$.
} 
China's cities suffer from very high pollution levels. With ongoing urbanization taking place in China, households are growing richer and more educated, and there are more people being exposed to these high levels of local public bads. Real estate prices are likely to reflect both of these facts. We find that real estate prices are lower in high pollution areas and this discount is growing over time. Given that ambient air quality has recently improved in several of China's cities, this rising capitalization evidence suggests that demand for clean air is rising in China.

We have generated these facts using traditional hedonic methods but exploiting an important, plausibly exogenous source of variation in local air pollution. Building on recent work in environmental economics by Bayer, Keohane and Timmins (2009), we have exploited cross-boundary flows in pollution from origin to destination to provide new hedonic estimates of the value of avoiding air pollution. Our calculations show that on average, a $10 \%$ decrease of the imported pollution from neighbors is associated with a $1.8 \%$ increase in home prices.

Future research could use similar methods to study quality of life impacts in other regional affected areas including Japan's and South Korea's cities. If China's emissions significantly affect other nearby nations, then this social damage is unlikely to be internalized as various air pollution policies are considered for adoption (Sigman 2002). 


\section{References}

Ai, N. 2003. Socioeconomic Impact Analysis of Yellow-dust Storms: A Case Study in Beijing, China. Unpublished Master Thesis, MIT

Almond, D., Chen Y., Greenstone, M., and Li,H. Winter Heating or Clean Air? Unintended Impacts of China's Huai River Policy, American Economic Review Papers and Proceedings. 99(2),2009: 184-190.

Andrews, S. Inconsistencies in Air Quality Metrics: 'Blue Sky' days and $\mathrm{PM}_{10}$ concentrations in Beijing, Environmental Research Letters 3, 2008: 034009

Bayer, P., Keohane, N. and Timmins, C. Migration and hedonic valuation: The case of air quality. Journal of Environmental Economics and Management, 58(1), 2009: 1-14.

Blomquist, G., Berger, M. and Hoen, John. New Estimates of Quality of Life in Urban Areas. American Economic Review. 78, 1988: 89-107.

Chau, K.W., Wong,S.K., Chan,A. T. and Lam,K. How do People Price Air Quality:

Empirical Evidence from Hong Kong, presented at the 12th Annual Conference of the Pacific Rim Real Estate Society, Auckland, New Zealand,2006: 22-25.

Chen, Y., Ginger, Z., Kumar, N., Shi, G. The Promise of Beijing: Evaluating the Impact of the 2008 Olympic Games on Air Quality, NBER Working Paper 16907.http://www.nber.org/papers/w16907

Chun, Y. The Yellow-sand Phenomenon Recorded in the "Joseon Wangjosillok" (in Korean).Korean J. Meteorol. Soc, 36(2), 2000: 285-292.

Dockery, D.W., Pope C.A. III, Xu, X. et al. An Association Between Air Pollution and Mortality in Six U.S. cities, N. Engl. J. Med. 329, 1993: 1753-1759.

Edgilis. Outdoor Air Pollution in Asian Cities: Challenges and Strategies - Hong Kong Case Study, Singapore, June 2009.

Gyourko, J. and Joesph, T. The structure of local public finance and the quality of life. Journal of Political Economy. 91(4), 1991: 774-806.

Kahn, M. E. The Silver Lining of Rust Belt Manufacturing Decline. Journal of Urban Economics, 46(3), 1999: 360-376.

Liu, J., Mauzerall, D.L. and Horowitz, L.W. Source-receptor Relationships Between East Asian Sulfur Dioxide Emissions and Northern Hemisphere Sulfate Concentrations. Atmos. Chem. Phys. 8, 2008: 3721-3733.

McKendry, I.G., Hacker,J.P.,Stull,R.,Sakiyama,S.,Mignacca,D. and Reid, K. Long-range transport of Asian dust to the Lower Fraser Valley, British Columbia, Canada. J. Geophys.Res., 106, 2001: 18361-18370.

Pope, C.A. III, Burnett, R.R., Thun, M.J., et al. Lung Cancer, Cardiopulmonary Mortality and Long-term Exposure to Fine Particulate Air Pollution. Journal of the 
American Medical Association, 287, 2002: 1132-1141.

Rosen, S. Markets and Diversity. American Economic Review, American Economic Association, 92(1), 2002: 1-15.

Saikawa, E., Naik, V., Horowitz, L.W., Liu, J. and Mauzerall, D.L. Present and Potential Future Contributions of Sulfate, Black and Organic Carbon Aerosols from China to Global Air Quality, Premature Mortality and Radiative Forcing, Atmospheric Environment, 43, 2009: 2814-2822.

Selden, T. M. and Song, D. Q. Neoclassical Growth, the J Curve for Abatement, and the Inverted U Curve for Pollution. Journal of Environmental Economics and Management, 29(2), 1995: 162-168.

Sigman, H. International Spillovers and Water Quality in Rivers: Do Countries Free Ride? American Economic Review, American Economic Association, 92(4), 2002: 1152-1159.

Simonich, S. Response to Comments on "Atmospheric Particulate Matter Pollution during the 2008 Beijing Olympics", Environmental Science \& Technology 43, 2009: 7590-7591.

Tang, X., Shao, M., Hu, M., Wang, Z., and Zhang, J. Comment on "Atmospheric Particulate Matter Pollution during the 2008 Beijing Olympics", Environmental Science \& Technology 43, 2009: 7588.

Tong, D.Q. and Mauzerall, D.L. Summertime State-Level Source-Receptor Relationships between Nitrogen Oxide Emissions and Downwind Surface Ozone Concentrations over the Continental United States. Environmental Science \& Technology, 42(21), 2008: 7976-7984.

Vennemo, H., Aunan,K., Lindhjem,H. and Seip, H. M. Environmental Pollution in China: Status and Trends. Review of Environmental Economics and Policy,3(2), 2009: $1-22$.

Wang X., Mauzerall, D.L. Evaluating Impacts of Air Pollution in China on Public Health: Implications for Future Air Pollution and Energy Policies. Atmos. Environ, 40, 2006: 1706-1721.

Wang W., Primbs, T., Tao, S., and Simonich, S.M. Atmospheric Particulate Matter Pollution during the 2008 Beijing Olympics, Environmental Science\& Technology, 43, 2009: 5314-5320. World Bank. Cost of Pollution in China. Washington, DC: World Bank,2007a.

World Bank. World Development Indicators 2007. Washington, DC: World Bank, $2007 b$.

World Bank. Cost of Pollution in China. Washington, DC: World Bank, 2009.

Yao, X., Xu, X., Sabaliauskas, K., and Fang, M. Comment on "Atmospheric Particulate Matter Pollution during the 2008 Beijing Olympics”, Environmental Science \& 
Technology 43, 2009: 7589.

Zabel, J. \& K. A. Kiel, 2000. "Estimating the Demand for Air Quality in Four U.S. Cities," Land Economics, vol. 76(2), pages 174-194

Zheng, S. Q., Fu, Y. M. and Liu, H. Y. Demand for Urban Quality of Living in China: Evidence from Cross-City Land Rent Growth. Journal of Real Estate Finance and Economics, 38, 2009: 194-213.

Zheng, S. Q.and Kahn, M. E. Land and Residential Property Markets in a Booming Economy: New Evidence from Beijing. Journal of Urban Economics, 63, 2008:

743-757.

Zheng,Siqi, Matthew E. Kahn, and Hongyu Liu. 2010. "Towards a System of Open Cities in China: Home Prices, FDI flows and Air Quality in 35 Major Cities. Regional Science and Urban Economics, 40: 1-10. 


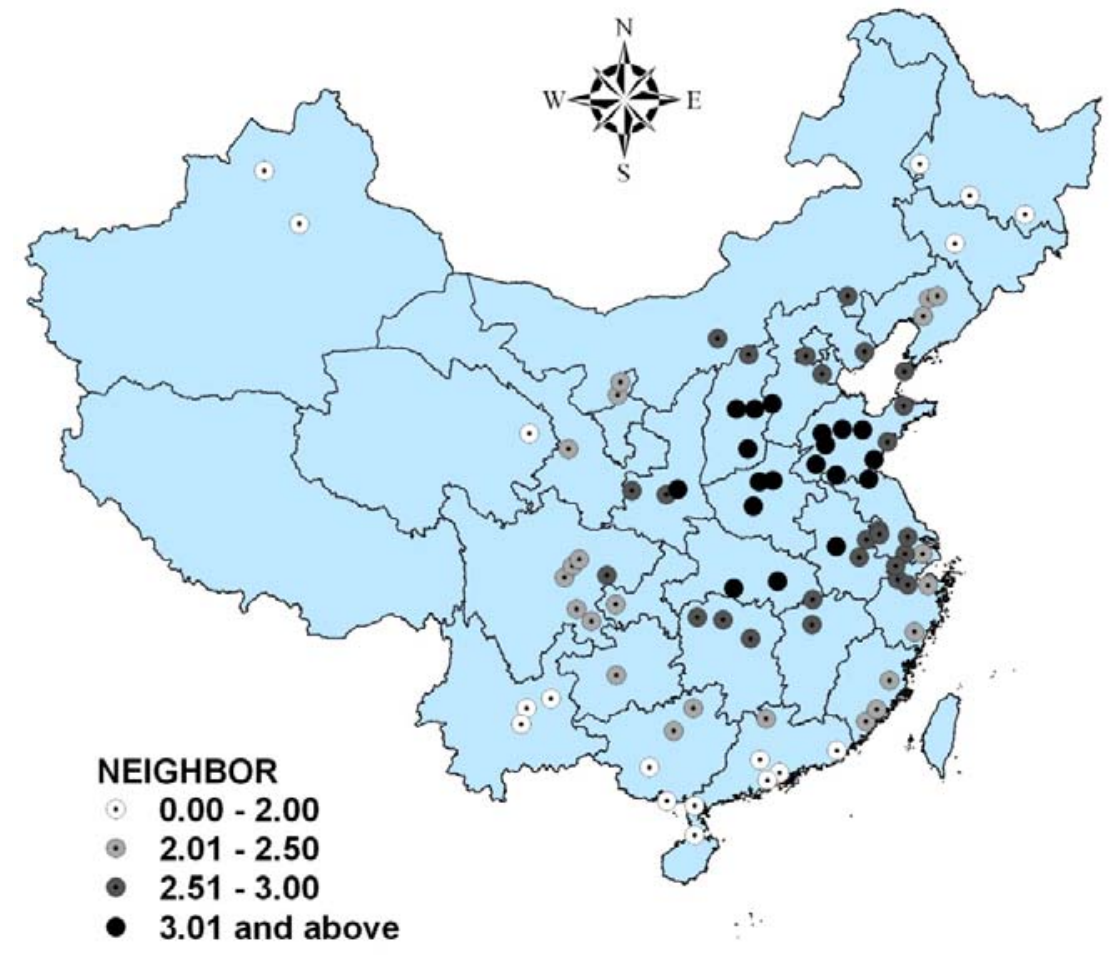

Figures 1: Distribution of NEIGHBOR or Imported Emissions in 2007 
Table 1: Variable Definitions and Summary Statistics

\begin{tabular}{|c|c|c|c|c|c|}
\hline Variable & Definition & Year & Obs. & Mean & Std. Dev. \\
\hline$H P$ & $\begin{array}{l}\text { Average sale price of newly-built homes } \\
\left(\mathrm{RMB} / \mathrm{m}^{2}\right)\end{array}$ & $2006 \sim 2008$ & 255 & 3255.7 & 2097.8 \\
\hline$P M$ & PM10 concentration in air $\left(\mathrm{mg} / \mathrm{m}^{3}\right)$ & $2006 \sim 2008$ & 255 & 0.093 & 0.026 \\
\hline POP & $\begin{array}{l}\text { Non-agricultural population } \\
\text { (million) }\end{array}$ & $2006 \sim 2008$ & 255 & 1.711 & 1.931 \\
\hline POP1985 & $\begin{array}{l}\text { Historical non-agricultural population } \\
\text { size (million) in } 1985\end{array}$ & 1985 & 81 & 0.846 & 1.101 \\
\hline MANU & $\begin{array}{l}\text { The output share of manufacturing } \\
\text { industry }(\%)\end{array}$ & $2006 \sim 2008$ & 255 & 44.0 & 10.6 \\
\hline RAIN & Total rain fall $(\mathrm{mm})$ & 2007 & 85 & 927.9 & 415.9 \\
\hline STORM & $\begin{array}{l}\text { The distance to the origin of sandstorm } \\
(\mathrm{km})\end{array}$ & $2006 \sim 2008$ & 255 & 1992.0 & 503.9 \\
\hline NEIGHBOR & Imported pollution from neighbor cities & $2006 \sim 2008$ & 255 & 2.559 & 0.673 \\
\hline TEMP_INDEX & Temperature discomfort index & 2007 & 85 & 18.1 & 5.5 \\
\hline$T E A \_S T U$ & Teacher/student ratio & $2006 \sim 2008$ & 255 & 0.068 & 0.015 \\
\hline SICKBED & $\begin{array}{l}\text { Number of beds in hospitals and clinic } \\
\text { per-capita }\end{array}$ & $2006 \sim 2008$ & 255 & 0.008 & 0.003 \\
\hline NONEAST & $\begin{array}{l}\text { Binary: } 1=\text { city in the central or western } \\
\text { region; } 0=\text { in the east region }\end{array}$ & - & 255 & 0.541 & 0.499 \\
\hline NORTH_BORDER & $\begin{array}{l}\text { Binary: } 1=\text { northern cities adjacent to } \\
\text { Huai River, } 0=\text { otherwise }\end{array}$ & 一 & 255 & 0.106 & 0.308 \\
\hline NORTH & $\begin{array}{l}\text { Binary: } 1=\text { northern cities with winter } \\
\text { heating (north of Huai River), } \\
0=\text { otherwise }\end{array}$ & - & 255 & 0.353 & 0.479 \\
\hline WAGE & $\begin{array}{l}\text { City mean annual wage per worker } \\
\text { (RMB) }\end{array}$ & $2006 \sim 2008$ & 255 & 26312.2 & 7143.7 \\
\hline
\end{tabular}


Table 2: PM10 Production Across 85 cities

\begin{tabular}{|c|c|c|c|c|c|c|}
\hline & (1) & (2) & (3) & (4) & (5) & (6) \\
\hline Year & \multicolumn{2}{|c|}{2006} & \multicolumn{2}{|c|}{2007} & \multicolumn{2}{|c|}{2008} \\
\hline $\log (P M)$ & \multicolumn{2}{|c|}{ OLS } & \multicolumn{2}{|c|}{ OLS } & \multicolumn{2}{|c|}{ OLS } \\
\hline $\log (P O P)$ & $\begin{array}{c}0.098^{* * *} \\
(2.87)\end{array}$ & $\begin{array}{c}0.109^{* * *} \\
(3.57)\end{array}$ & $\begin{array}{c}0.114^{* * *} \\
(3.66)\end{array}$ & $\begin{array}{c}0.122^{* * *} \\
(4.22)\end{array}$ & $\begin{array}{c}0.107^{* * *} \\
(3.38)\end{array}$ & $\begin{array}{l}0.111^{* * *} \\
(3.62)\end{array}$ \\
\hline$M A N U$ & $\begin{array}{l}-0.003 \\
(-1.19)\end{array}$ & $\begin{array}{c}-0.00163 \\
(-0.66)\end{array}$ & $\begin{array}{c}-0.0003 \\
(-0.13)\end{array}$ & $\begin{array}{l}0.001 \\
(0.23)\end{array}$ & $\begin{array}{l}0.002 \\
(0.64)\end{array}$ & $\begin{array}{l}0.002 \\
(0.87)\end{array}$ \\
\hline $\log (R A I N)$ & $\begin{array}{c}-0.325^{* * *} \\
(-5.79)\end{array}$ & $\begin{array}{c}-0.191^{* *} \\
(-2.01)\end{array}$ & $\begin{array}{c}-0.261^{* * *} \\
(-5.03)\end{array}$ & $\begin{array}{l}-0.167^{*} \\
(-1.85)\end{array}$ & $\begin{array}{c}-0.207^{* * *} \\
(-3.92)\end{array}$ & $\begin{array}{l}-0.103 \\
(-1.07)\end{array}$ \\
\hline $\log (S T O R M)$ & & $\begin{array}{c}-0.466^{* * *} \\
(-3.64)\end{array}$ & & $\begin{array}{c}-0.333^{* * *} \\
(-2.74)\end{array}$ & & $\begin{array}{l}-0.323^{*} \\
(-2.51)\end{array}$ \\
\hline $\log (N E I G H B O R)$ & & $\begin{array}{c}0.381^{* * *} \\
(4.35)\end{array}$ & & $\begin{array}{c}0.315^{* * *} \\
(3.74)\end{array}$ & & $\begin{array}{c}0.258^{* * *} \\
(2.88)\end{array}$ \\
\hline NORTH_BORDER & & $\begin{array}{l}-0.026 \\
(-0.26)\end{array}$ & & $\begin{array}{l}0.063 \\
(0.67)\end{array}$ & & $\begin{array}{c}0.0493 \\
(0.49)\end{array}$ \\
\hline NORTH & & $\begin{array}{l}-0.020 \\
(-0.22)\end{array}$ & & $\begin{array}{l}-0.015 \\
(-0.18)\end{array}$ & & $\begin{array}{l}0.001 \\
(0.01)\end{array}$ \\
\hline Constant & $\begin{array}{l}-0.046 \\
(-0.11) \\
\end{array}$ & $\begin{array}{l}2.107^{* *} \\
(2.64) \\
\end{array}$ & $\begin{array}{l}-0.67^{*} \\
(-1.74) \\
\end{array}$ & $\begin{array}{l}0.900 \\
(1.18) \\
\end{array}$ & $\begin{array}{c}-1.158^{* * *} \\
(-2.93)\end{array}$ & $\begin{array}{l}0.361 \\
(0.44)\end{array}$ \\
\hline $\begin{array}{l}\text { Joint F-test for IV } \\
\text { variables }\end{array}$ & & $8.77^{* * *}$ & & $6.92^{* * *}$ & & $4.44^{* * *}$ \\
\hline Observations & 85 & 85 & 85 & 85 & 85 & 85 \\
\hline$R^{23}$ & 0.345 & 0.550 & 0.321 & 0.500 & 0.250 & 0.391 \\
\hline
\end{tabular}

statistics in parentheses

${ }^{*} p<0.10,{ }^{* *} p<0.05,{ }^{* * *} p<0.01$ 
Table 3: Cities Importing the Most Pollution

\begin{tabular}{rrrr}
\hline Rank & 2006 & $\mathbf{2 0 0 7}$ & $\mathbf{2 0 0 8}$ \\
\hline 1 & Pingdingshan & Pingdingshan & Pingdingshan \\
2 & Jining & Wuhan & Jining \\
3 & Wuhan & Jining & Wuhan \\
4 & Jinzhou & Jinzhou & Kaifeng \\
5 & Kaifeng & Kaifeng & Jinzhou \\
6 & Jiujiang & Jiujiang & Jiujiang \\
7 & Zhengzhou & Zhengzhou & zhengzhou \\
8 & Zaozhuang & Zaozhuang & Zaozhuang \\
9 & Hefei & Hefei & Hefei \\
10 & Changzhi & Changzhi & Changzhi \\
\hline
\end{tabular}


Table 4: Cross-City Hedonic Home Price Regressions for 85 Cities

\begin{tabular}{|c|c|c|c|c|c|c|c|c|c|}
\hline & (1) & (2) & (3) & (4) & (5) & (6) & (7) & (8) & (9) \\
\hline Year & & 2006 & & \multicolumn{3}{|c|}{2007} & \multicolumn{3}{|c|}{2008} \\
\hline $\log (\mathrm{HP})$ & OLS & IV1 & IV2 & OLS & IV1 & IV2 & OLS & IV1 & IV2 \\
\hline $\log (P O P)$ & $\begin{array}{c}0.363^{* * * *} \\
(8.10)\end{array}$ & $\begin{array}{c}0.365^{* * *} \\
(7.82)\end{array}$ & $\begin{array}{c}0.322^{* * *} \\
(5.43) \\
(\mathrm{IV})\end{array}$ & $\begin{array}{c}0.402^{* * *} \\
(8.72)\end{array}$ & $\begin{array}{c}0.422^{* * *} \\
(8.64)\end{array}$ & $\begin{array}{c}0.382^{* * *} \\
(6.20) \\
(I V)\end{array}$ & $\begin{array}{c}0.343^{* * *} \\
(7.82)\end{array}$ & $\begin{array}{c}0.392^{* * *} \\
(8.28)\end{array}$ & $\begin{array}{c}0.369^{* * *} \\
(6.31) \\
(I V)\end{array}$ \\
\hline TEMP_INDEX & $\begin{array}{l}-0.007 \\
(-1.04)\end{array}$ & $\begin{array}{l}-0.008 \\
(-1.08)\end{array}$ & $\begin{array}{l}-0.010 \\
(-1.21)\end{array}$ & $\begin{array}{l}-0.006 \\
(-0.79)\end{array}$ & $\begin{array}{l}-0.005 \\
(-0.70)\end{array}$ & $\begin{array}{l}-0.007 \\
(-0.82)\end{array}$ & $\begin{array}{l}-0.008 \\
(-1.20)\end{array}$ & $\begin{array}{l}-0.006 \\
(-0.83)\end{array}$ & $\begin{array}{l}-0.007 \\
(-0.86)\end{array}$ \\
\hline TEA_STU & $\begin{array}{l}4.703 \\
(1.56)\end{array}$ & $\begin{array}{l}4.693 \\
(1.54)\end{array}$ & $\begin{array}{l}5.126 \\
(1.44)\end{array}$ & $\begin{array}{l}0.409 \\
(0.12)\end{array}$ & $\begin{array}{l}0.383 \\
(0.11)\end{array}$ & $\begin{array}{l}0.591 \\
(0.15)\end{array}$ & $\begin{array}{l}1.177 \\
(0.65)\end{array}$ & $\begin{array}{l}1.064 \\
(0.61)\end{array}$ & $\begin{array}{l}0.533 \\
(0.27)\end{array}$ \\
\hline $\log (S I C K B E D)$ & $\begin{array}{c}0.361^{* * *} \\
(2.85)\end{array}$ & $\begin{array}{c}0.294^{* * *} \\
(2.39)\end{array}$ & $\begin{array}{l}0.126 \\
(0.90)\end{array}$ & $\begin{array}{c}0.517^{* * *} \\
(3.73)\end{array}$ & $\begin{array}{c}0.426^{* * *} \\
(3.21)\end{array}$ & $\begin{array}{l}0.251^{*} \\
(1.67)\end{array}$ & $\begin{array}{l}0.215^{* *} \\
(2.16)\end{array}$ & $\begin{array}{l}0.168^{*} \\
(1.75)\end{array}$ & $\begin{array}{c}0.0763 \\
(0.72)\end{array}$ \\
\hline $\log (P M)$ & $-0.253^{* *}$ & $\begin{array}{c}-0.309^{*} \\
(\mathrm{IV}) \\
(-1.75)\end{array}$ & $\begin{array}{c}-0.243 \\
(\mathrm{IV}) \\
(-124)\end{array}$ & $\begin{array}{c}-0.366^{* * *} \\
(-265)\end{array}$ & $\begin{array}{c}-0.583^{* * *} \\
(I V) \\
(-278)\end{array}$ & $\begin{array}{c}-0.515^{* *} \\
\text { (IV) }\end{array}$ & $-0.283^{* *}$ & $\begin{array}{c}-0.761^{* * *} \\
\text { (IV) }\end{array}$ & $\begin{array}{c}-0.713^{* * *} \\
\text { (IV) }\end{array}$ \\
\hline NONEAST & $\begin{array}{c}(-2.05) \\
-0.417^{* * *} \\
(-5.40)\end{array}$ & $\begin{array}{c}(-1.75) \\
-0.395^{* * *} \\
(-4.84)\end{array}$ & $\begin{array}{c}(-1.24) \\
-0.434^{* * *} \\
(-4.68)\end{array}$ & $\begin{array}{c}(-2.65) \\
-0.459^{* * *} \\
(-5.98)\end{array}$ & $\begin{array}{c}(-2.78) \\
-0.410^{* * *} \\
(-5.16)\end{array}$ & $\begin{array}{c}(-2.20) \\
-0.458^{* * *} \\
(-5.02)\end{array}$ & $\begin{array}{c}(-2.06) \\
-0.382^{* * *} \\
(-5.10)\end{array}$ & $\begin{array}{c}(-3.11) \\
-0.322^{* * *} \\
(-4.26)\end{array}$ & $\begin{array}{c}(-2.74) \\
-0.386 \\
(-4.66)\end{array}$ \\
\hline Constant & $\begin{array}{l}8.959^{* * * *} \\
(13.25)\end{array}$ & $\begin{array}{l}8.496^{* * *} \\
(10.46)\end{array}$ & $\begin{array}{c}7.879^{* * *} \\
(8.71)\end{array}$ & $\begin{array}{c}9.855^{* * *} \\
(13.05)\end{array}$ & $\begin{array}{c}8.851^{* * * *} \\
(9.68)\end{array}$ & $\begin{array}{c}8.219^{* * * *} \\
(8.01)\end{array}$ & $\begin{array}{l}8.634^{* * *} \\
(14.35)\end{array}$ & $\begin{array}{c}7.151^{* * *} \\
(8.43)\end{array}$ & $\begin{array}{l}6.922^{* * * *} \\
(7.61)\end{array}$ \\
\hline $\begin{array}{l}\text { Year } \\
\text { Fixed Effects }\end{array}$ & No & No & No & No & No & No & No & No & No \\
\hline $\begin{array}{l}\text { Observations } \\
R^{2}\end{array}$ & $\begin{array}{c}85 \\
0.647\end{array}$ & $\begin{array}{c}85 \\
0.642\end{array}$ & $\begin{array}{c}81 \\
0.540\end{array}$ & $\begin{array}{c}85 \\
0.668\end{array}$ & $\begin{array}{c}85 \\
0.670\end{array}$ & $\begin{array}{c}81 \\
0.562\end{array}$ & $\begin{array}{c}85 \\
0.618\end{array}$ & $\begin{array}{c}85 \\
0.642\end{array}$ & $\begin{array}{c}81 \\
0.551\end{array}$ \\
\hline
\end{tabular}


Table 5: Cross-City Hedonic Wage Regressions for 85 Cities

\begin{tabular}{|c|c|c|c|c|c|c|}
\hline & (1) & (2) & (3) & (4) & (5) & (6) \\
\hline Year & \multicolumn{2}{|c|}{2006} & \multicolumn{2}{|c|}{2007} & \multicolumn{2}{|c|}{2008} \\
\hline $\log (W A G E)$ & OLS & IV & OLS & IV & OLS & IV \\
\hline $\log (P O P)$ & $\begin{array}{c}0.139^{* * *} \\
(5.20)\end{array}$ & $\begin{array}{c}0.143^{* * *} \\
(5.21)\end{array}$ & $\begin{array}{c}0.144^{* * *} \\
(5.84)\end{array}$ & $\begin{array}{c}0.141^{* * *} \\
(5.40)\end{array}$ & $\begin{array}{c}0.116^{* * * *} \\
(4.72)\end{array}$ & $\begin{array}{c}0.108^{* * *} \\
(4.00)\end{array}$ \\
\hline TEA_STU & $\begin{array}{l}2.717 \\
(1.57)\end{array}$ & $\begin{array}{l}2.841 \\
(1.64)\end{array}$ & $\begin{array}{l}0.699 \\
(0.40)\end{array}$ & $\begin{array}{l}0.613 \\
(0.35)\end{array}$ & $\begin{array}{c}0.00651 \\
(0.01)\end{array}$ & $\begin{array}{c}0.0223 \\
(0.02)\end{array}$ \\
\hline $\log (S I C K B E D)$ & $\begin{array}{c}0.241^{* * *} \\
(3.23)\end{array}$ & $\begin{array}{c}0.219^{* * *} \\
(3.01)\end{array}$ & $\begin{array}{c}0.272^{* * *} \\
(3.70)\end{array}$ & $\begin{array}{c}0.239^{* * *} \\
(3.31)\end{array}$ & $\begin{array}{l}0.103^{*} \\
(1.87)\end{array}$ & $\begin{array}{l}0.110^{*} \\
(1.97)\end{array}$ \\
\hline $\log (P M 10)$ & $\begin{array}{c}-0.0784 \\
(-1.14)\end{array}$ & $\begin{array}{l}-0.127 \\
(-1.30)\end{array}$ & $\begin{array}{l}-0.124^{*} \\
(-1.80)\end{array}$ & $\begin{array}{l}-0.122 \\
(-1.17)\end{array}$ & $\begin{array}{c}-0.0509 \\
(-0.71)\end{array}$ & $\begin{array}{l}-0.0920 \\
(-1.02)\end{array}$ \\
\hline NONEAST & $\begin{array}{c}-0.207^{* * *} \\
(-4.54)\end{array}$ & $\begin{array}{c}-0.195^{* * *} \\
(-4.05)\end{array}$ & $\begin{array}{c}-0.186^{* * *} \\
(-4.59)\end{array}$ & $\begin{array}{c}-0.179^{* * *} \\
(-4.18)\end{array}$ & $\begin{array}{c}-0.144^{* * *} \\
(-3.47)\end{array}$ & $\begin{array}{c}-0.153^{* * *} \\
(-3.53)\end{array}$ \\
\hline Constant & $\begin{array}{l}10.88^{* * * *} \\
(27.17)\end{array}$ & $\begin{array}{l}10.65^{* * *} \\
(22.58) \\
\end{array}$ & $\begin{array}{l}11.20^{* * * *} \\
(27.83)\end{array}$ & $\begin{array}{l}11.05^{* * *} \\
(22.70)\end{array}$ & $\begin{array}{l}10.73^{* * *} \\
(32.97)\end{array}$ & $\begin{array}{l}10.96^{* * *} \\
(24.68)\end{array}$ \\
\hline Observations & 85 & 85 & 85 & 85 & 85 & 85 \\
\hline$R^{2}$ & 0.470 & 0.473 & 0.485 & 0.473 & 0.373 & 0.378 \\
\hline
\end{tabular}

